\title{
Dampak COVID-19 Terhadap Dinamika Pembelajaran Di Indonesia
}

\author{
Abd. Rahim Mansyur \\ Dosen Tetap Universitas Muslim Indonesia \\ abdrahimmansyur.umi@gmail.com
}

\begin{abstract}
Abstrak
Pembelajaran merupakan instrumen penting mencerdaskan kehidupan Bangsa. Sebagai suatu sistem penting dalam pendidikan, pembelajaran diselenggarakan sebagai ruang interaksi terbangunnya relasi guru dan peserta didik mengembangkan potensi kognitif, psikomotorik dan afektif. Hal ini harus didukung dengan dinamika pembelajaran yang berjalan secara efektif dan suasana belajar internal yang membuat peserta didik tertarik belajar. Pembelajaran juga dapat dipengaruhi oleh faktor eksternal, seperti dengan adanya wabah Covid-19. Realitas menunjukkan bahwa dinamika pembelajaran di Indonesia saat ini terganggu oleh wabah Covid-19 yang memberikan dampak diantaranya; 1) sekolah dialihkan ke rumah melalui proses pembelajaran daring; 2) terjadi transformasi media pembelajaran berbasis teknologi melalui penggunaan Wathshap Group, Zoom, Google Classroom, WebEx, Youtube, dan saluran TV (TVRI); 3) penyesuaian metode pembelajaran; 4) penyesuaian evaluasi pembelajaran untuk penentuan standar kenaikan kelas dan kelulusan; dan 5) tuntutan kolaborasi orangtua peserta didik di rumah sebagai pengganti guru mengontro pembelajaran anak.
\end{abstract}

Kata Kunci: Dampak Covid-19, Dinamika Pembelajaran

\section{Pendahuluan}

Pembelajaran sejatinya dilakukan melalui interaksi guru dengan siswa dalam suasana lingkungan belajar. Esensi pembelajaran ini merupakan pendampingan yang dilakukan pendidik untuk mentransmisikan ilmu kepada peserta didik. Oleh karena itu, secara sederhana pembelajaran dapat dimaknai sebagai suatu proses pencerahan yang dilakukan guru untuk membantu siswa mendapatkan pembelajaran dan mampu memahami bahan pembelajaran yang diberikan.

Paradigma terhadap esensi pembelajaran semacam itu telah menjadi klasik dengan adanya krisis Covid-19 yang telah mengubah paradigma pendidikan dan pembelajaran di dunia. Krisis pandemi ini tidak hanya menyerang organ pernapasan manusia, namun juga menghentikan organ sistem pendidikan dan pembelajaran yang diselenggarakan secara normal melalui pembelajaran tatap muka di sekolah. Seluruh dunia disibukkan dengan pencegahan penularan Covid-19 sehingga diterapkan penghentian seluruh aktivitas di luar rumah dan perkantoran, termasuk sekolah ditutup untuk sementara.

Indonesia merupakan salah satu negara terdampak wabah menjadikan social distancing dan physical distancing sebagai kebijakan pembatasan jarak sosial dan fisik berdampak pada penghentian proses pembelajaran di sekolah. Seluruh penyelenggaraan pendidikan diliburkan, bahkan ujian nasional juga terancam. Krisis di depan mata sedang berlangsung memaksa semua komponen pendidikan menginovasi pembelajaran jarak jauh melalui daring atau pembelajaran dalam jaringan. Hal ini dimaksudkan agar proses pembelajaran tetap berlangsung di tengah mewabahnya pademi Covid-19.

Salah satu model pembelajaran yang adaptif dengan situasi pandemi ini ialah pembelajaran daring karena dilakukan tatap muka jarak jauh antara pendidik dan siswa. Pembelajaran daring merupakan salah satu model pembelajaran yang dilakukan dengan menggunakan perangkat 
teknologi di tengah pandemi saat ini. Efektifitas model pembelajaran ini sangat ditentukan oleh sistem jaringan telekomunikasi sebagai perangkat penunjang yang paling utama.

Model pembelajaran yang dilakukan secara Daring menuntut kreativitas dan keterampilan guru menggunakan teknologi. Peserta didik juga diharapkan mampu mengakses jaringan aplikasi yang digunakan dalam pembelajaran seperti Zoom dan beberapa aplikais lainnya. Meskipun dapat menjadi solusi penunjang pembelajaran di tengah pandemi Covid-19, namun terdapat kendala kaena problem lain muncul berkaitan dengan kurangnya akses jaringan yang tidak lancar, beban biaya data untuk mengakses aplikasi yang mahal, ketidaksiapan guru mengadaptasi teknologi, orang tua yang kurang sinergis dengan guru mendampingi anak belajar di rumah, hingga siswa yang terputus secara emosional dan sosial dengan siswa lainnya.

Beberapa kendala tersebut terjadi secara merata di seluruh wilayah di Indonesia. Di Kota Makassar yang termasuk salah satu kota terbesar di luar Pulau Jawa dengan dukungan pembangunan yang maju masih dirasakan kurang maksimal dalam hal pelaksanaan pembelajaran Daring selama pandemi karena faktor jaringan yang timbul tenggelam atau hilang dari tangkapan handphone atau leptop guru dan siswa. Dengan demikian, maka pembelajaran Daring di pelosokpelok wilayah yang minim akses jaringan akan jauh lebih berat dilakukan.

Kajian berkaitan dengan dampak Covid-19 terhadap dinamika pembelajaran dalam dunia pendidikan di Indonesia sangat menarik diulas sebagai bentuk pembacaan ilmiah terhadap fenomena pembelajaran yang berlangsung saat ini. Media telah melaporkan berbagai kasus pembelajaran selama pandemi di seluruh Indonesia yang dapat dijadikan sebagai data penelitian pustaka (Library Research), sehingga sangat penting menjadi perhatian praktisi pendidikan, dosen, maupun guru mengkaji fenomena ini sebagai peluang mengagas paradigma baru pembelajaran di masa depan. Berdasarkan penjelasan tersebut, penulis tertarik untuk melakukan kajian dengan judul; "Dampak Covid-19 terhadap Dinamika Pembelajaran di Indonesia". Berdasarkan pendahuluan di atas, rumusan masalah penulisan ini yaitu; "Bagaimankah gambaran dampak covid-19 terhadap dinamika pembelajaran di Indonesia?"

\section{Pembahasan}

\subsection{Hakikat Pembelajaran}

Permbelajaran berkaitan dengan suatu proses interaksi yang melibatkan guru dan peserta didik. Pembelajaran dilakukan secara berkesinambungan untuk mengelola potensi peserta didik memperoleh ilmu pengetahuan. Proses interaksi dalam pembelajaran akan berjalan dengan baik jika guru kreatif memanfaatkan berbagai media dan metode dalam pembelajaran untuk menstimulus peserta didik belajar dengan motivasi yang baik dalam pembelajaran. Sudirman (2004: 45) mengemukakan pembelajaran sebagai suatu proses berubah, sehingga maksud dari suatu proses pembelajaran dimaknai sebagai suatu usaha sadar mengubah aspek tingkah laku.

Proses pencapaian perubahan dalam pembelajaran melibakan usaha guru sebagai figur pencerah yang dapat menata perilaku peserta didik. Dengan demikian, guru menjadi teladan dalam hal tingkah laku peserta didik. Untuk dapat melakukan hal tersebut, guru memerlukan berbagai perangkat pendukung seperti metode dalam menghadapi situasi peserta didik yang kompleks. Sejalan dengan hal ini, Sutikno (2009: 32) menjelaskan pembelajaran merupakan segala upaya yang dilakukan guru sebagai pendidik agar terjadi proses belajar pada diri siswa. Lebih lanjut 
dikemukakan bahwa secara implisit terdapat kegiatan memilih dalam pembelajaran, menetapkan dan mengembangkan metode untuk mencapai hasil pembelajaran.

Hasil pembelajaran yang diharapkan berkaitan dengan perubahan pada diri peserta didik. Hamalik (Djamarah, 2002: 15) makna perubahan pada pembelajaran melibatkan perubahan persepsi dan perilaku termasuk perbaikan perilaku. Belajar juga diartikan suatu proses menuju perubahan, tetapi perubahan perubahan dalam arti belajar menunjukkan ciri tertentu, seperti; a) perubahan terjadi secara sadar, b) perubahan bersifat continue dan fungsional, c) perubahan bersifat positif fan aktif, d) perubahan bertujuan dan terarah, dan e) perubahan seluruh aspek tingkah laku.

Tentunya pencapaian semua perubahan tersebut di atas sangat ditentukan oleh berbagai variabel penting dalam pembelajaran. Faktor materi ajar juga sangat menentukan ketertarikan peserta didik dalam pembelajaran. Tidak kreatifnya guru mengemas materi ajar akan menyebabkan kejenuhan peserta didik mengikuti pembelajaran. Hal ini dilihat dari segi relasi psikologisnya, sebagaimana dijelaskan oleh Ibnu Sina (Nata, 2003: 74-75) bahwa secara psikologis suatu materi pelajaran tidak dapat dijelaskan dengan satu cara saja dan harus dicapai dengan cara yang sesuai dengan perkembangan psikologis peserta didik. Dengan demikian, penyampaian materi haruslah disesuaikan dengan karakteristik materi tersebut untuk menyeimbangkan relevansi antara materi dan metode yang digunakan dalam pembelajaran.

Berdasarkan penjelasan tersebut di atas, dapat disimpulkan bahwa pembelajaran pada hakikatnya merupakan upaya menuju penyadaran yang dilakukan oleh guru kepada peserta didik. Peserta didik yang berubah dalam pembelajaran apabila terdapat ciri perubahan dalam arti sadar secara continue dan fungsional dalam arti aplikasi perilaku. Peserta didik yang sadar haruslah dalam arti positif dan aktif terarah pada nilai kebaikan seluruh aspek tingkah laku peserta didik. Dalam mencapai perubahan tersebut juga ditentukan oleh berbagai variabel, termasuk bahan ajar yang ditunjang dengan metode yang relevan dengan pertumbuhan psikologis peserta didik.

Materi ajar dan metode harus dipadukan dengan berbagai strategi guru yang dilakukan secara kreatif untuk meningkatkan daya tarik peserta didik mengikuti pelajaran. Selama masa krisis Covid-19, pembelajaran haruslah dilakukan secara kreatif melalui berbagai aplikasi Daring (dalam jaringan) atau yang disebut dengan pembelajaran online.

Virtualisasi pembelajaran semacam ini mendorong guru lebih memadatkan materi ajar yang didukung dengan metode yang tepat karena minimnya waktu dan resiko biaya aplikasi yang digunakan. Dengan demikian, bukan hanya perihal psikologis peserta didik yang harus menjadi fokus perhatian guru, akan tetapi guru dan peserta didik berada dalam satu situasi psikologis yang sama mengadaptasi situasi pembelajaran yang dilakukan secara Daring atau virtual.

\subsection{Tujuan Pembelajaran}

Seluruh rangkaian pembelajaran mengarah pada ketercapaian tujuan sebagai arah untuk memperoleh hasil yang maksimal. Oleh karena itu, tujuan pembelajaran harus menjadi pertimbangan penting dalam melakukan rancangan pembelajaran. Secara teoritik, tujuan pembelajaran meliputi tujuan kognitif, tujuan psikomotorik, dan tujuan afektif. Tiga tujuan pembelajaran ini paling utama menjadi pertimbangan penting guru dalam perencanaan dan pengelolaan pembelajaran.

a. Tujuan Kognitif 
Tujuan kognitif berkaitan dengan aspek perilaku berfikir atau perilaku intelektual. Oleh karena itu, pembelajaran harus menjangkau aspek penalaran berfikir peserta didik. Bloom (Ibrahim, 1996: 72) menjelaskan enam tingkatan pada aspek kognitif yaitu; (1) tingkat pengetahuan, tingkatan ini berkaitan dengan kemampuan peserta didik mengenal dan mengingat materi pembelajaran; (2) tingkat pemahaman yaitu berkaitan dengan kemampuan peserta didik memahami dan memaknai materi yang dipelajari dalam pembelajaran; (3) tingkat penerapan, berkaitan dengan kemampuan peserta didik menggunakan pengetahuan yang diperoleh dalam memecahkan suatu persoalan; (4) tingkat analisis yaitu mengacu pada kemampuan peserta didik menelaah serta mengurai materi ajar menjadi komponen-komponen spesifik; (5) tingkat sintesis berkaitan dengan kemampuan mengkombinasikan berbagai konsep melalui kegiatan kreatif; dan (6) tingkat evaluasi yaitu kemampuan peserta didik merumuskan dan memberikan penilaian terhadap suatu peristiwa menggunakan standar norma tertentu.

\section{b. Tujuan Psikomotorik}

Tujuan psikomotorik dalam pembelajaran menstimulus respon gerak peserta didik secara aktif. Santrock (2007: 469) menjelaskan aspek psikomotor ini tidak hanya berkaitan dengan atletik semata, akan tetapi berkaitan juga dengan aktivitas menulis dengan tangan serta pengolahan katakata yang melibatkan gerakan tertentu.

Lebih lanjut kawasan psikomotor ini berkaitan dengan beberapa tingkatan yaitu; 1) persepsi, berkaitan dengan pengaktifan fungsi indera misalnya dengan mengenali warna; 2) kesiapan, berkaitan dengan kemampuan fisik maupun emosional melakukan gerakan; 3) respon terbimbing, berkaitan dengan gerakan sesuai contoh yang diberikan; 4) respon mekanis, berkaitan dengan gerakan mandiri yang tidak lagi disertai contoh; 5) respon kompleks, berkaitan dengan pengembangan gerakan mandiri secara tepat; 6) adaptasi, berkaitan dengan kemampuan penyesuaian gerakan dengan standar yang ada sebagai suatu prasyarat semisalnya pertandingan; dan 7) kreativitas, berkaitan dengan kemampuan membuat gerakan baru secara mandiri.

Berdasarkan penjelasan tersebut dapat disimpulkan bahwa tujuan psikomotorik dalam pembelajaran menstimulus potensi fisik peserta didik serta membentuk kemampuan gerakan mereka secara aktif hingga mandiri menciptakan gerakatan sendiri secara kreatif. Dengan demikian, pembelajaran haruslah dipandang sebagai suatu proses fisik dan mental yang dapat membuat peserta didik aktif dalam berbagai tingkatan tersebut.

\section{c. Tujuan Afektif}

Tujuan pembelajaran dari segi afektif mengarah pada pembentukan empatik yang melibatkan perasaan atau emosi yang menjadi dasar bagi peserta didik tumbuh menjadi manusia yang menghargai atau menghormati orang lain di lingkungannya.

Bloom (Winkel, 1987: 152) membagi ranah afektif menjadi beberapa tingakatan, yaitu; 1) penerimaan, berkaitan dengan kepekaan peserta didik menerima penjelasan guru; 2) partisipasi, berkaitan dengan kerelaan atau kesediaan untuk secara aktif turut serta dalam suatu kegiatan; 3) penilaian dan penentuan sikap, berkaitan dengan kemampuan menilai sesuatu dan menentukan sikap atas hasil penilaian terhadap sesuatu tersebut; 4) organisasi, berkaitan dengan kemampuan membentuk nilai pedoman hidup yang dapat menjadi pegangan dalam hidup; dan 5) pembentukan pola hidup, berkaitan dengan kemampuan penghayatan nilai kehidupan yang kemudian diserap menjadi milik pribadi untuk mengatur kehidupan sendiri. Atau dengan kata lain dalam Islam 
mampu menarik hikmah dari kenyataan hidup atau belajar dari pengalaman kisah-kisah kebijaksanaan.

Berdasarkan penjelasan tersebut, dapat disimpulkan bahwa tujuan pembelajaran secara afektif membentuk daya empatik peserta didik sehingga mereka menjadi pribadi yang peka terhadap kehidupan di sekeliling mereka. Peserta didik yang memiliki afektif yang baik akan mampu mengorganisir berbagai nilai positif di masyarakat serta mampu membedakan nilai-nilai negatif di lingkungan sosialnya. Nilai positif yang mereka pahami akan diserap sebagai suatu sistem nilai pengambilan sikap dan pembentukan kehidupan mereka di tengah masyarakat.

\subsection{Dinamika dalam Pembelajaran}

Pembelajaran sebagai suatu proses berlangsung secara dinamis karena berbagai situasi dan kondisi yang berubah-ubah dan dapat berpengaruh pada kualitas pembelajaran yang dilaksanakan. Tentunya dinamika pembelajaran yang kompleks juga memberikan dampak besar terhadap kemampuan peserta didik dalam capaian hasil pembelajaran. Hal ini dijelaskan oleh Sudjana (2020: 148) bahwa terdapat beberapa hal yang saling berpengaruh dalam suatu proses pembelajaran yaitu; kondisi pembelajaran, metode pembelajaran dan hasil pembelajaran.

\section{a. Kondisi Pembelajaran}

Kondisi pembelajaran dapat dijelaskan salah satu faktor yang dapat mempengaruhi hasil belajar guru dan peserta didik. Kondisi ini dapat dipahami datang secara internal maupun eksternal. Secara internal, penentuan metode maupun pengembangan strategi pembelajaran yang dilakukan oleh guru dapat menciptakan suatu kondisi pembelajaran yang baik dan mendorong peserta didik lebih termotivasi mengikuti pembelajaran. Ganguan akan terjadi secara internal apabila guru gagal menentukan metode dan strategi yang kurang tepat sehingga menyebabkan peserta didik jenuh mengikuti pembelajaran.

Kondisi pembelajaran juga dapat dipengaruhi secara eksternal, yakni pengaruh yang datang dari lingkungan belajar peserta didik. Lebih luas lagi kondisi lingkungan sekitar sekolah maupun di luar sekolah. Kebisingan motor di jalan raya dapat mengganggu konsentrasi pembelajaran. Lebih umum lagi seperti mewabahnya pademi Covid-19 merupakan kondisi eksternal yang memberikan pengaruh besar pada pembelajaran.

\section{b. Metode Pembelajaran}

Metode pembelajaran menjadi salah satu unsur penting dalam pembelajaran. Dinamika pembelajaran yang menarik sangat ditentukan oleh metode yang digunakan oleh guru selama proses pembelajaran. Oleh karena itu, metode pembelajaran merupakan suatu unsur yang menentukan dalam sistem pembelajaran untuk membuat pembelajaran lebih menarik dan memudahkan peserta didik memahami isi bahan ajar yang disampaikan oleh guru.

\section{c. Hasil Pembelajaran}

Hasil pembelajaran berkaitan dengan semua capaian yang dapat dijadikan sebagai ukuran menilai proses pembelajaran berhasil atau belum. Hal ini merupakan salah satu unsur penting pada bagian akhir dilaksanakannya proses pembelajaran yang dapat dikenali pada diri peserta didik berupa kemampuan kognitif, afektif, dan psikomotorik. Dengan demikian, hasil belajar ini dapat dipengaruhi oleh rangkaian pembelajaran yang dilakukan oleh guru termasuk pemilihan metode 
dan media yang digunakan sebagai instrumen pembelajaran. Seluruh unsur tersebut merupakan suatu rangkaian sistem yang tidak bisa terpisahkan.

Berdasarkan penjelasan tersebut dapat disimpulkan bahwa aspek kondisi belajar, metode pembelajaran dan hasil pembelajaran saling berpengaruh sebagai suatu sistem yang dinamis. Selain tiga hal tersebut dapat pula dikemukakan bahawa aspek lain yang dapat mempengaruhi dinamika pembelajaran seperti kepemimpinan kepala sekolah, ketersediaan sarana dan prasarana serta ketersediaan guru yang profesional di bidangnya.

\section{Hasil}

\subsection{Dampak Covid-19 terhadap Dinamika Pembelajaran}

Pembelajaran tidak selamanya berjalan dengan baik sesuai rencana yang telah disusun. Tujuan pembelajaran tidak selamanya dicapai secara maksimal karena dinamika pembelajaran yang dipengaruhi oleh banyak faktor. Situasi ini tentunya mempengaruhi aspek kognitif, psikomotorik dan afektif peserta didik berkembang dengan lamban. Saat ini, dunia yang dilanda Covid-19 secara masal menjadi faktor eksternal baru yang berpengaruh pada penyelenggaraan pendidikan di Indonesia.

Pelaksanaan pembelajaran di setiap sekolah dihentikan secara nasional oleh Pemerintah Pusat akibat wabah Covid-19. Penghentian proses pembelajaran dan seluruh pelayanan pendidikan lainnya dilaksanakan sebagai upaya pencegahan penularan Covid-19 berdasarkan Surat Edaran Mendikbud Nomor 4 Tahun 2020 tentang Pelaksanaan Kebijakan Pendidikan dalam Masa Darurat Penyebaran Corona Virus Disease (Covid-19). Wabah virus Covid-19 memberikan dampak besar pada pembelajaran di Indonesia, beberapa dampak secara faktual dapat diamati sebagai berikut.

\section{a. Sekolah dari Rumah}

Sekolah dari rumah merupakan istilah dapat mewakili seluruh aktivitas pembelajaran yang dilakukan oleh guru dan peserta didik di rumah masing-masing menggunakan perangkat teknologi yang tersedia. Pembelajaran yang sebelumnya dilaksanakan secara sentral di gedung sekolah harus dialihkan ke rumah akibat Covid-19. Pembelajaran selama Sekolah dari Rumah ini menggunakan sistem pembelajaran secara Daring (Dalam Jaringan) atau pembelajaran virtual.

Pembelajaran yang dilakukan dari rumah berpatokan pada Surat Edaran Mendikbud Nomor 4 Tahun 2020. Dalam surat edaran tersebut dijelaskan ketentuan belajar dari rumah dilaksanakan dengan ketentuan; 1) Belajar dilakukan secara daring atau jarak jauh untuk memberikan pengalaman bermakna bagi peserta didik. Pada poin ini diberikan pula kelonggaran bagi guru dan peserta didik tidak harus menuntaskan capaian kurikulum, khususnya kenaikan kelas maupun kelulusan; 2) Fokus utama pembelajaran dari rumah yaitu pendidikan kecakapan antara lain berkaitan dengan pademi Covid-19. Dengan demikian, guru harus memiliki wawasan edukasi Covid-19 di luar materi ajar mata pelajaran yang harus diajarkan kepada peserta didik; 3) Aktivitas dan tugas pembelajaran diberkan secara bervariasi sesuai minat dan kondisi masing-masing peserta didik, teruma atas pertimbangan kesenjangan akses atau fasilitas belajar di rumah; dan 4) Produk belajar mendapat umpan balik bersifat kualitatif dan berguna dari guru, tanpa suatu keharusan memberikan skor dalam bentuk nilai kuantitatif. Dengan demikian, penilaian yang dilakukan secara otentik melalui pengamatan guru terhadap peserta didik selama mengikuti pembelajaran daring.

Berdasarkan penjelasan tersebut dapat disimpulkan bahwa pembelajaran daring merupakan satu-satunya saluran desain kelas virtual bagi terselenggaranya Sekolah dari Rumah. Hasil 
pengamatan penulis menunjukkan bahwa pelaksanaan pembelajaran ini tidak terikan pada aturan formal sekolah lainnya seperti siswa harus berseragam sekolah, meskipun demikian rangkaian pembelajaran yang dilakukan merupakan proses formal yang harus diikuti oleh peserta didik dengan batasan kesopanan berpakaian selama pembelajaran berlangsung.

\section{b. Transformasi Media Pembelajaran}

Media pembelajaran menjadi instrumen penting penyampaian pesan dalam proses pembelajaran. Guru menggunakan media untuk memudahkan proses pembelajaran yang dilakukan. Selain itu, media juga akan meudahkan peserta didik memahami materi pelajaran yang diberikan. Sebaimana dijelaskan oleh Risman (2012: 46) bahwa media merupakan alat bagi suatu pekerjaan, sehingga suatu pekerjaan bisa terselesaikan dengan baik dengan hasil memuaskan. Dengan demikian, media merupakan wahana penyalur belajar atau penyalur pesan selama proses pembelajaran.

Fungsi media pembelajaran dapat mengefektifkan proses pembelajaran karena membangkitkan minat dan motivasi peserta didik mengikuti pembelajaran. Stimulus yang baik juga dapat dihasilkan melalui penggunaan media pembelajaran karena berpengaruh secara psikologis pada diri peserta didik. Media yang lazim digunakan dalam pembelajara yaitu audio visual, media cetak seperti buku pelajaran, terutama media yang paling klasik seperti papan tulis yang umumnya digunakan guru dalam pembelajaran.

Adanya Covid-19 berdampak pada peralihan penggunaan media. Media pembelajaran bertransformasi lebih canggih menggunakan perangkat teknologi jaringan. Hasil pengamatan penulis menunjukkan bahwa guru dan peserta didik harus menggunakan media pembelajaran baru dengan lingkungan dan suasan pembelajaran baru. Beberapa transformasi penggunaan media pembelajaran di antaranya ialah penggunaan Wathshap Group untuk diskusi dan penugasan, penggunaan aplikasi Zoom, Google Classroom, WebEx untuk konferensi tatap muka pembelajaran secara daring, dan penggunaan youtube untuk eksplorasi materi secara visual dan pemakaian jaringan televisi seperti TVRI untuk pendalaman materi pelajaran. Semua jenis media ini, meskipun terasa menjadi solusi selama pandemi, namun memiliki berbagai kelemahan.

Berbagai kelemahan diantaranya berkaitan dengan daya dukung jaringan yang sering terganggu sehingga tatap muka virtual pembelajaran tidak maksimal. Selain itu, tidak semua peserta didik memiliki handphone berbasis android serta kesenjangan ekonomi menjadi kendala serius penggunaan berbagai media pembelajaran berbasis daring tersebut. Bahkan beberapa aplikasi Zoom dihimbau untuk tidak digunakan sebagai media pembelajaran karena membahayakan data pengguna dan menguras biaya data yang mahal. Pemanfaatan siaran telivisi seperti TVRI juga tidak serta merta peserta didik dibiarkan sendiri mengikuti materi pelajaran yang disiarkan, namun harus mendapatkan pengawasan orangtua di rumah.

\section{c. Penyesuaian Metode Pembelajaran}

Metode pembelajaran tidak bisa dipisahkan dari media pembelajaran karena memiliki hubungan yang saling berkaitan. Media yang bagus dan canggih tanpa didukung dengan metode guru yang baik dan kreatif akan menjadikan pembelajaran tidak maksimal. Sebagaimana dijelaskan Ghofir, dkk (1983: 79) bahwa metode mengajar menjadi alat mencapai tujuan. Apabila seorang guru kurang tepat memilih metode mengajar akan menyebabkan kekaburan tujuan. Seorang pendidik juga sangat dituntut menguasai beragam metode pembelajaran, tidak hanya bersifat teoritis, tetapi juga mampu mengoperasionalkan semua metode yang dikuasainya dengan baik. 
Pandemi Covid-19 telah menyebabkan pembelajaran dilakukan dari rumah juga berdampak pada penyesuaian metode pembelajaran yang dilakukan oleh guru. Guru harus mampu memilih metode yang bagus dalam situasi waktu yang singkat selama pembelajaran menggunakan aplikasi dalam jaringan. Pengamatan penulis menunjukkan bahwa guru lebih mengandalkan metode ceramah dan penugasan.

Penyampaian materi pelajaran juga dipadatkan untuk menghemat waktu dan biaya dalam penggunaan aplikasi. Sehingga, pembelajaran dirasakan kurang maksimal karena terbentur biaya pemakaian aplikasi dalam jaringan. Dinamika penggunaan metode tersebut tidak maksimal karena disebabkan oleh faktor kelengkapan fasilitas. Dalam pembelajaran daring, fasilitas yang paling utama adalah jaringan telekomunikasi yang baik dan harus ditunjang dengan biaya data yang terjangkau. Sementara tidak semua peserta didik berada pada level ekonomi yang mampu mencukupi tuntutan biaya penggunaan aplikasi tersebut.

Berkaitan dengan pemilihan metode ini sebagaimana dijelaskan oleh Djamarah dan Zain (2010: 78-81) bahwa terdapat beberapa faktor yang dapat menjadi pertimbangan dalam memilih metode pembelajaran, yaitu; berpedoman tujuan, situasi perbedaan individu peserta didik, kemampuan guru, sifat bahan ajar, situasi kelas, kelengkapan fasilitas serta kelebihan dan kekurangan metode pengajaran. Dengan demikian, guru yang melaksanakan pembelajaran dari di tengah pandemi Covid-19 harus mampu menyederhanakan bahan ajar agar sesuasi dengan situasi kelas daring yang dilakukan dengan pertimbangan utama dukungan fasilitas yang digunakan.

\section{d. Penyesuaian Evaluasi Pembelajaran}

Evaluasi merupakan upaya pengendalian mutu pembelajaran yang mendorong akuntabilitas mutu proses pendidikan. Sistem evaluasi juga menjadi instrumen untuk mengkur hasil belajar peserta didik yang telah mengikuti proses pembelajaran. Selama masa pandemi, sistem evaluasi pembelajaran seperti; 1) Penilaian Harian yang dilaksanakan setiap selesai KD, 2) Penilaian Tengah Semester yang dilaksanakan setiap dua bulan belajar, dan 3) Penilaian Akhir Tahun menjelang kenaikan kelas dirasakan kurang maksimal karena beberapa alasan di antaranya peserta didik disemua jenjang pendidikan sekolah mengisi soal ujian secara daring tanpa pengawasan guru secara ketat.

Sistem evaluasi pembelajaran berbasis Ujian Nasional dibatalkan berdasarkan Surat Edaran Mendikbud Nomor 4 Tahun 2020. Dengan demikian, pada tahun 2020 UN tidak menjadi syarat kelulusan peserta didik untuk masuk ke jenjeng pendidikan lebih tinggi (Perguruan Tinggi). Untuk Ujian Sekolah, kelulusan juga dilakukan penyesuaian sistem evaluasinya dalam bentuk portofolio, nilai rapor, prestasi peserta didik sebelumnya, sistem penugasan, pelaksanaan tes daring, atau asesmen jarak jauh. Secara khusus, dalam surat edaran Mendikbud (2020) tersebut juga mengatur ketentuan bagi sekolah-sekolah yang belum melaksanakan Ujian Sekolah sebagai berikut.

Pertama, untuk kelulusan SD/sederajat ditentukan berdasarkan nilai lima semester terakhir kelas 4, kelas 5, dan kelas 6. Selanjutnya nilai semester genap kelas 6 digunakan sebagai tamabahan nilai kelulusan. Kedua, untuk kelulusan SMP dan SMA juga ditentukan kelulusan berdasarkan nilai lima semester terakhir dan nilai semester genap kelas 9 dan kelas 12 digunakan sebagai tambahan nilai kelulusan, dan Ketiga, untuk kelulusan SMK ditentukan berdasarkan tiga nilai yaitu nilai rapor, nilai praktik kerja lapangan, portofolio dan nilai praktik selama lima semester terakhir. Kemudian nilai semester genap tahun terakhir digunakan sebagai tamabahan nilai kelaulusan. 
Berdasarkan penjelasan tersebut dapat disimpulkan bahwa Covid-19 telah memberikan dampak terhadap paradigma pengukuran hasil pembelajaran di setiap jenjang pendidikan sekolah. Konsekuensi logis di tengah krisis ini ialah dilakukannya penyesuaian yang jika dianalisis dirasakan kurang efektif dalam menentukan standar kenaikan kelas maupun kelulusan sekolah peserta didik karena mengandalkan nilai yang telah dicapai peserta didik sebelumnya. Dengan demikian, institusi pendidikan tidak memperoleh gambaran otentik tentang perkembangan hasil belajar peserta didik selama masa pandemi.

\section{e. Kolaborasi Orangtua Peserta Didik}

Bersekolah dari rumah dengan seluruh rangkaian pembelajaran daring menghidupkan kolaborasi penuh orangtua peserta didik. Orangtua menjadi pengganti guru selama belajar di rumah. Orang tua yang sebelumnya lebih mencurahkan waktunya mencari nafkah kembali mengaktifkan peranannya secara total mengawasi anak di rumah. Situasi kiris Covid-19 setidaknya berdampak pada peranan orang tua dengan berkolaborasi menyelamatkan diri anak sekaligus waktu belajar anak. Dengan demikian, ada dua peranana orang tua yang hidup sekaligus, menurut Arifin (2007: 87) yaitu orantua berperan mendidik anak secara langsung dan berperan sebagai pelindung anak. Kedua peranan ini sangat sesuai dengan situasi pandemi saat ini.

Kolaborasi orangtua di rumah sangat menentukan pencapaian tujuan pembelajaran. Selama mengemban tugas kolaborasi ini orang tua perlu memerhatikan beberapa faktor dalam memberikan pendidikan terhadap anak, sebagaimana Slameto (2000: 66), yang penulis jelaskan sebagai berikut.

\section{1) Relasi antara keluarga}

Relasi orangtua dengan anak dalam kelurga sangat penting. Hubungan yang baik akan membantu anak menyelesaikan tugas-tugas belajarnya. Akan tetapi, kontrol ketat dari orangtua selama belajar di rumah terkadang menjadi masalah tersendiri bagi anak. Sehingga terkadang terjadi masalah perkengkaran antara anak dengan orangtua yang bisa saja disebabkan oleh kejenuhan dan lain sebagainya. Oleh karena itu, orangtua harus mampu menghandirkan suasana nyaman dalam keluarga yang dapat menjamin pembelajaran anak selama pandemi.

2) Suasana rumah tangga dan keluarga

Suasana rumah tangga dan keluarga yang nyaman akan sangat membantu anak belajar dengan mandiri di rumah. Untuk itu, orang tua harus fleksibel memberikan kontrol terhadap pembelajaran anak. Semua orang tentunya memiliki kejenuhan yang sama selama masa karantina di rumah. Oleh karena itu, suasana rumah tangga dan keluarga harus diciptakan oleh orang tua untuk menunjang psikologi belajar anak selama belajar di rumah.

3) Keadaan ekonomi keluarga

Kolaborasi orang tua harus mampu memenuhi kebutuhan belajar anak di rumah seperti fasilitas meja, buku, alat tulis menulis. Kebutuhan yang paling utama ialah tersedianya handphone atau gadget yang bisa digunakan untuk terkoneksi dengan jaringan dalam pembelajaran daring. Dengan demikian, orang tua dalam berkolaborasi harus memiliki finansial untuk menunjang pembelajaran anak di rumah.

4) Pehatian orangtua

Perhatian orangtua harus diberikan terhadap anak selain untuk mengevaluasi belajar anak juga memberikan motivasi anak untuk semangat dalam mengikuti belajar daring. Bentuk perhatian ini juga sebagai bentuk proteksi dan edukasi anak terhadap bahaya Covid-19. Perhatian akan 
membuat anak merasa nyaman berada di lingkungan rumah karena menemukan curahan kasih sayang dari orangtua. Namun, harus digaris bawahi bahwa bentuk perhatian ini terkadang harus dilakukan secara persuasi dengan suasana dialogis santai dengan anak agar anak tidak merasa tertekan dengan situasi di dalam rumah.

Berdasarkan penjelasan tersebut dapat disimpulkan bahwa Covid-19 memberikan dampak secara umum terhadap pembelajaran di Indonesia. Beberapa dampak diantaranya; 1) sekolah dialihkan ke rumah melalui proses pembelajaran daring; 2) terjadi transformasi media pembelajaran berbasis teknologi melalui penggunaan Wathshap Group, Zoom, Google Classroom, WebEx, Youtube, dan saluran TV; 3) penyesuaian metode pembelajaran; 4) penyesuaian evaluasi pembelajaran untuk penentuan standar kenaikan kelas dan kelulusan; dan 5) tuntutan kolaborasi orangtua peserta didik di rumah sebagai pengganti guru mengontro pembelajaran anak.

\section{Kesimpulan}

Berdasarkan pembahan di atas, dapat dirumuskan kesimpulan sebagai berikut.

Pembelajaran merupakan suatu proses interaksi antara guru dan peserta didik menggunakan berbagai sarana dalam pembelajaran. Pembelajaran dilakukan untuk mencapai tujuan perubahan perilaku peserta didik. Dengan demikian, dalam proses pembelajaran usaha guru sebagai figur pencerah merupakan aspek utama proses pencapaian perubahan dalam pembelajaran. Oleh karena itu, guru harus menjadi teladan tingkah laku yang akan dicontoh oleh peserta didik.

Secara teoritis pembelajaran dilakukan untuk mencapai tujuan kognitif yaitu perilaku berfikir dan intelektual, tujuan psikomotorik berkaitan dengan respon gerak fisik secara aktif peserta didik, dan tujuan afektif yakni aspek empatik peserta didik. Tujuan pembelajaran ini akan dicapai apabila didukung dinamika pembelajaran yang berjalan dengan baik. Beberapa faktor yang dapat mempengaruhi dinamika pembelajaran ialah kondisi pembelajaran, metode pembelajaran dan hasil belajar.

Dinamika pembelajaran di Indonesia saat ini terganggu secara eksternal oleh krisis wabah Covid-19. Bebebrapa dampak diantaranya; 1) sekolah dialihkan ke rumah melalui proses pembelajaran daring; 2) terjadi transformasi media pembelajaran berbasis teknologi melalui penggunaan Wathshap Group, Zoom, Google Classroom, WebEx, Youtube, dan saluran TV; 3) penyesuaian metode pembelajaran; 4) penyesuaian evaluasi pembelajaran untuk penentuan standar kenaikan kelas dan kelulusan; dan 5) tuntutan kolaborasi orangtua peserta didik di rumah sebagai pengganti guru mengontro pembelajaran anak. 


\section{DAFTAR PUSTAKA}

Arifin. 2007. Hubungan Timbal Balik Pendidikan Agama Islam di Lingkungan Sekolah dan Keluarga. Jakarta: Bulan Bintang.

Djamarah, Syaiful Bahri. 2002. Psikologi Belajar. Jakarta: PT. Rineka Cipta.

Djamarah, Syaiful Bahri dan Aswan Zain. 2010. Strategi Belajar Mengajar. Jakarta: Rineka Cipta.

Ghofir dkk, Zuhairini Abdul. 1983. Metode Khusus Pendidikan Agama. Surabaya: Usaha Nasional.

Ibrahim, R. 1996. Perencanaan Pengajaran. Jakarta: Rienaka Cipta.

Mendikbud. 2020. Surat Edaran Nomor Nomor 4 Tahun 2020 Tentang Pelaksanaan Kebijakan Pendidikan dalam Masa Darurat Penyebaran Corona Virus Disease (COVID-19), salinan, diakses dari google.com

Nata, Abuddin. 2003. Pemikiran Para Tokoh Pendidikan Islam. Jakarta: Raja Grafindo Persada.

Rusman. 2012. Belajar dan Pembelajaran Berbasis Komputer. Bandung: Alfabeta.

Sardirman. 2004. Interaksi dan Motifasi Belajar. Jakarta: PT. Raja Grafindo Persada.

Santrock, John W. 2007. Psikologi Pendidikan (terj. Tri Wibowo). Jakarta: Kencana.

Slameto. 2000. Belajar dan Faktor-Faktor yang Mempengaruhinya. Jakarta: Rineka Cipta.

Sudjana, Nana. 2010. Dasar-Dasar Proses Belajar Mengajar. Bandung: Sinar Baru Algensindo.

Sutikno, M. Sobry. 2009. Belajar dan Pembelajaran. Bandung: Prospect.

Winkel, W. S. 1987. Psikologi Pengajaran. Jakarta: Gramedia. 